Academic Platform Journal of Engineering and Science

\title{
Optimal Okuma Şartlarının Taguchi Yöntemiyle Belirlenmesi
}

\author{
*11Mustafa Yilmaz, ${ }^{2}$ Muhammed Emre Keskin \\ ${ }^{1}$ Atatürk Üniversitesi Endüstri Mühendisliği Bölümü, ERZURUM, mustafay@atauni.edu.tr, \\ ${ }^{2}$ Atatürk Üniversitesi Endüstri Mühendisliği Bölümü, ERZURUM, emre.keskin@atauni.edu.tr, iD \\ Research Paper \\ Received Date: 03.02.2018 \\ Accepted Date: 07.08.2018
}

$\ddot{O} z$

Bilgisayarların günlük hayatın ve iş hayatının ayrılmaz bir parçası olduğu bilinmektedir. Birçok meslek grubunda insanlar bilgisayar ekranından metin okuyarak çalışmaktadır. Bu çalışmada, özellikle üniversitede çalışan akademisyenler için bilgisayar ekranından yapacakları okumalarda en iyi ortam şartlarının belirlenmesi amaçlanmıştır. Bu amaçla, bilgisayardan yapılan okumaları etkileyen üç unsur ışık seviyesi, müzik seviyesi ve punto büyüklüğü olarak ele alınmış ve her unsur için dört farklı seviye belirlenmiştir. Unsurların okuma hızını en yüksek yapacak seviyelerini belirlemek için az sayıda deneyle en iyi unsur seviyelerini tespit eden Taguchi Yöntemi tercih edilmiştir. Çalışma esnasında $\mathrm{L}_{16}\left(4^{5}\right)$ ortogonal deney tasarım planı kullanılmış ve okuma hızı performans ölçütü olarak belirlenmiştir. Elde edilen sonuçlara göre ekran 1şık seviyesinin hafif, punto büyüklüğünün en fazla ve müzik seviyesinin hafif olduğu ortamın yapılacak okuma çalışması için ideal olduğu anlaşılmıştır.

Anahtar kelimeler: Taguchi metodu, Okuma şartları, Deney tasarımı

\section{Determination of Optimal Reading Conditions by Taguchi Method}

\author{
*1 Mustafa Yilmaz, ${ }^{2}$ Muhammed Emre Keskin \\ ${ }^{1}$ Industrial Engineering Department of Ataturk University, ERZURUM, mustafay@atauni.edu.tr \\ ${ }^{2}$ Industrial Engineering Department of Ataturk University, ERZURUM, emre.keskin@atauni.edu.tr
}

\begin{abstract}
Computers are regarded as an indispensable part of daily and business life. In many occupations, people work by reading from computer screens. This study intends to identify the optimum environment conditions for reading on computer screens especially for academicians. To this end, light level, music level, and font size were accepted as the factors influencing reading, and four different levels were set for each. To identify the factor levels that maximize the reading speed, Taguchi method, which produces the optimal factor levels with minimum experiment, was used. $\mathrm{L}_{16}\left(4^{5}\right)$ orthogonal experimental design was employed during the experimental studies, and the reading speed was selected as the performance measure. The results revealed that low light level, maximum font type size, and low music volume are the optimum reading conditions.
\end{abstract}

Keywords: Taguchi method, Reading conditions, Experiment design

\section{INTRODUCTION}

In today's world, access to information has become remarkably fast, and especially with internet becoming widespread, it has been very practical. Many people have now easy and reliable access to the required information and documents by means of reading on computer screens. For reading on computer screen, it is critical that such conditions as light, font size and noise are optimum to assure efficiency and eye health.
This study intends to identify the optimum environment conditions for reading on computer screens especially for academicians. Reading is of utmost importance for academic work. The academicians are obliged to read on the computer screen because there is often substantial material to read. As it is well known, reading speed is affected by the light level in the environment, the font size in the text and the noise level of the environment. There might be other factors affecting the reading speed apart from these three, yet they are thought to be related with the conditions in the reader's personal environment, rather than with general reading 
conditions. Thus, the level of light in the environment, the font size and the noise level appear to be factors that have an impact on reading performance and eye health as to reading on the computer screen. Obviously, noise level in the environment affects the reading speed. Therefore, it should be taken as a factor that influences the reading speed. However, level of music listened from the computer was preferred in this study because, in experimental studies, it is impossible to fix the noise level in the environment. Hence, the factor name is taken as music volume throughout the text which is considered to indicate noise level of the environment.

In brief, the above mentioned three factors affecting reading were taken, and four different levels were determined for each factor. The experiment was designed based on the following values: low-medium-high-very high brightness for light level; $80 \%-120 \%-160 \%-200 \%$ of reading text for font size; low-medium-high-very high levels of music volume. The experiments were repeated three times, each time with a novel text taken from different parts of a pdf document.

An experiment design modifies the factors affecting a process to improve its performance, to monitor and interpret the variables on the outcome of the process. That is, it aims to collect information concerning the overall performance of a process, identify the factors that affect the quality characteristics of this process, and determine the optimal values of the components to improve the quality of the process ([1]).In the experiment design, the independent variable is called the factor, and the values the independent variable takes are called factor levels. Experimental design is important as it reveals the level of factors' effect on the dependent variable.

The following section presents a review of the related literature, followed by section 3, which explains the Taguchi Method. Part 4 presents the details of the experimental design and focuses on the results. The Conclusion part discusses the results and reveals the optimal reading conditions.

\section{LITERATURE REVIEW}

Many studies in the literature have experiment design employing the Taguchi method. The main reason for the widespread use of the method is that it can determine the optimal levels of the parameters that influence the experiment design with relatively fewer experimental cycles. Since there is a substantial number of related works, this part includes especially the studies conducted in the last 10 years and published in reputable magazines. In addition, studies employing the Taguchi method are naturally found in disciplines, such as chemistry and physics, where empirical experimental studies are performed in a laboratory environment.

The Taguchi method is often used to investigate the best operating conditions, especially for lathe and milling machines. For example, Zhang et al. ([2]) applied the
Taguchi method in their 2007 study to determine the optimal values of the factors affecting surface hardness in end milling work. The study regarded that three factors, feed rate, shaft rotation speed, and cut depth, affect the surface hardness. The orthogonal array $\mathrm{L}_{9}\left(3^{4}\right)$ was chosen for the Taguchi test design, and whether the effect of each parameter on the surface was significant or not and the levels of the significant ones which produce the minimum surface hardness were identified. In the same year, Nalbant et al. ([3]) applied the Taguchi method to find the factors that affect surface hardness during turning on lathe machine, and different from Zhang et.al, they considered the approach angle of the cut tool as one of the factors affecting hardness, while ignoring the spindle speed because they did not use milling cutter but lathe cutter. Three levels were set for each factor, and experiments were conducted according to orthogonal array $\mathrm{L}_{9}\left(3^{4}\right)$ experiment design. Based on these studies, Tzeng et al. [4] used the Taguchi method in 2009 to determine the optimal levels of conditions affecting CNC lathe turning. The average surface hardness, the maximum surface hardness, and surface roundness were selected as target functions, and depth of cut, cut speed, feed speed, and density of the cutting fluid were selected as the experiment parameters. Three levels were set for each experiment factor, thus experiment design $\mathrm{L}_{9}\left(3^{4}\right)$ was applied. The results of the experiment revealed that, among all the factors, the depth of the cut has the greatest impact on the average surface hardness, and cut speed has the greatest impact on the maximum surface hardness and surface roundness. Another study using experimental design Taguchi method in CNC machines was carried out by Kilickap ([5]) in 2010, who aimed to investigate the optimal levels of the parameters of cut depth, cut speed, and cut angle for a particular composite material. Finally, the ideal working conditions of the lathe were investigated by Asiltürk and Neşeli ([6]) in 2012. Similarly, cut depth, cut speed, and feed speed were selected as significant factors, and the extent to which they affect the hardness of the target was analyzed. Experiments were performed according to orthogonal experimental design $\mathrm{L}_{9}\left(3^{3}\right)$; in addition, the results obtained were consolidated by response surface method.

Determination of the factors that affect the test result by Taguchi method is also applied in other sectors. For example, Engin et al. ([7]) employed the Taguchi method in 2008 to determine the optimal values of factors affecting color removal from textile products. Intensity of chemical discoloration, rate of chemical feed, waste water flow rate, and the bed size studied were regarded as significant factors in the experiment. Four levels were set for two components, and two levels were set for the remaining two levels. $\mathrm{L}_{16}\left(4^{2} \times 2^{2}\right)$ orthogonal array was chosen as Taguchi experiment design, and ultimately optimum levels of significant factors were decided. Another example is Lin et al's ([8]) research in 2009. Performance of a particular conductive ceramic in machines that transmit voltage was tested. The parameters were set as machine polarity ratio, maximum and bypass current rates, and current pulse rate, and performance criteria were selected as material abrasion 
rate, electrode deposition rate, and surface hardness. Experiments were run in $\mathrm{L}_{18}$ experiment design, and the optimal values of the significant factors were found. In his work [9] the same year (2009), Eşme applied the Taguchi method to determine the factors affecting the surface tension force produced during welding, as a result of which electrode force, welding current value, electrode radius, and welding time were selected. $\mathrm{L}_{18}\left(3^{4}\right)$ orthogonal experiment design was chosen as each factor was assigned three levels, and the significant factors' optimal values that affect the experiment results were found out.

Kamaruddin et al. ([10]) applied the Taguchi method to determine the optimal levels of quality of a mold injection product in 2010. Shrinkage effect was taken as a performance indicator, and injection speed, melting temperature, injection pressure, holding pressure, holding time, and cooling time were accepted as the components that affect the experiment. The injection speed was assigned 2, and other factors were assigned 3 levels, and $\mathrm{L}_{18}\left(2 \times 3^{7}\right)$ orthogonal experiment design was implemented. The last two columns in the experiment design was filled arbitrarily, not signifying any significant factor.

Kuo et al. ([11]) applied the Taguchi method to determine the optimal operating conditions for flat plate collectors, using collector tube material, inner plate material, number of collector tubes, and radius of the collector tube, absorption type, and thickness of the insulation material for the base as significant factors. Experiments were performed at two levels for the collector tube material, and at three levels for the other factors, wherein $\mathrm{L}_{18}\left(2 \times 3^{5}\right)$ orthogonal experimental plan was administered. Sapakal and Telsang ([12]) also used Taguchi method to identify the optimal values of factors that influence welding. They selected welding quality, production amount, and welding cost as the performance criteria, and welding current rate, welding voltage, welding speed, and weld depth as the factors affecting these criteria. L9 orthogonal experiment design was used to determine the levels of significant factors. Kotcioğlu et al. ([13]) researched into six components affecting the performance of a heat transformer. These components include ratio of pipe depth and surface length, ratio of flap and surface length, flap pitch, Reynolds number, flow rate, and pressure. The experiments were performed in $\mathrm{L}_{25}\left(5^{6}\right)$ orthogonal array, with each factor having five levels. The factor levels allowing for an ideal experiment were calculated. Research carried out by Sivasakthivel et al. ([14]) was based on similar principles, analyzing the optimal working conditions of a heat pump. The heat pump inlet temperature, the outer surface temperature of the lens, the evaporator dryness rate, and the evaporator outer surface temperature were accepted to be factors affecting the heat pump process. Each factor had four levels.

On the other hand, Kumar et al. ([15]) applied the Taguchi method in a very interesting field. In their study, the factors affecting the rate of biodiesel production were selected as methanol and oil ratio, reaction time, reaction temperature, and catalyst concentration. Three levels were set for each. Experiments were performed on the basis of the $\mathrm{L}_{9}\left(3^{4}\right)$ orthogonal test plan and the parameter values that will enable the fastest biodiesel production were found. Similarly, Dhawane et al. ([16]) expanded Kumar and his colleagues' study by focusing on the factors affecting the rate of biodiesel production. The significant factors and the orthogonal test plan used are the same as those used in Kumar et al. The two studies differed as regards the organic material used as raw material in biodiesel manufacturing. Finally, Mousavi et al. ([17]) studied the problem of site location selection and inventory planning, and solved largescale examples of the mathematical model they developed by meta-intuitive means. They used the Taguchi Method to explore the optimal values of the parameters that will influence the performance of the meta-intuition they used. $\mathrm{L}_{9}\left(3^{4}\right)$ orthogonal array was used, and the optimum intuitive parameters were identified.

A summary of Taguchi experiment design studies of the literature mentioned below is provided in Table 1 with respect to authors' names, publication year, application area and the employed orthogonal array. There are not many studies in the literature focusing on the factors affecting the reading speed. The ones that do so have not approached the subject from the viewpoint of experimental design. For example, in their study dated 1932, Paterson and Tinker (18) investigated how the font style affects reading speed, but they did not perform an empirical, experiment based, study. Following these studies, very few studies were conducted to analyze the factors affecting the reading speed. Chung ([20]) investigated whether font size in the handwritten texts influences the reading speed. Finally, Baynal et al ([21]) used experimental design in 2011 to identify the optimal levels of the factors affecting the reading speed. Music level, reading aloud and silent reading, font size, gender, and use of glasses were selected as parameters affecting reading, and the number of words read in a fixed duration was selected as the performance indicator. This study is similar to the present study as regards content, yet it has certain limitations. First two levels were set for each of the significant factors. A parameter should have at least two levels when the performance is not affected by the degree of the parameter, e.g. when the music volume factor is involved. The research disregarded this.

On the other hand, full factorial experimental design was used; that is, experiments were conducted for any probable scenario. Before carrying out experiments for probable scenarios, the present study used Taguchi Experimental Design to identify the optimal levels of significant factors. In addition, it analyzed the effect of light level on reading speed. That is, the present study has significance as it focuses on a subject, on which there have been few studies, and it uses the right method to produce the optimal results with fewer experiments. 
Table 1. Summary of Taguchi experiment design studies of the literature

\begin{tabular}{|l|l|l|l|}
\hline Author(s) & Year & Application Area & Orthogonal Array \\
\hline Zhang et al. & 2007 & Material processing technology & $\mathrm{L}_{9}\left(3^{4}\right)$ \\
\hline Nalbant et al. & 2007 & Material processing technology & $\mathrm{L}_{9}\left(3^{4}\right)$ \\
\hline Tzeng et al. & 2009 & Material processing technology & $\mathrm{L}_{9}\left(3^{4}\right)$ \\
\hline Kilickap & 2010 & Drilling process & $\mathrm{L}_{16}\left(4^{5}\right)$ \\
\hline Asiltürk and Neşeli & 2012 & Measurement system & $\mathrm{L}_{9}\left(3^{3}\right)$ \\
\hline Engin et al. & 2008 & Textile sector & $\mathrm{L}_{16}\left(4^{2} \times 2^{2}\right)$ \\
\hline Lin et al. & 2009 & Manufacturing process & $\mathrm{L}_{18}$ \\
\hline Eşme & 2009 & Welding process & $\mathrm{L}_{18}\left(3^{4}\right)$ \\
\hline Kamaruddin et al. & 2010 & Plastic manufacturing & $\mathrm{L}_{18}\left(2 \times 3^{7}\right)$ \\
\hline Kuo et al. & 2011 & Solar energy collector manufacturing & $\mathrm{L}_{18}\left(2 \times 3^{5}\right)$ \\
\hline Sapakal and Telsang & 2012 & MIG welding & $\mathrm{L}_{9}$ \\
\hline Kotcioğlu et al. & 2013 & Heat transfer & $\mathrm{L}_{25}\left(5^{6}\right)$ \\
\hline Sivasakthivel et al. & 2014 & Heating and cooling system & $\mathrm{L}_{9}\left(3^{4}\right)$ \\
\hline Kumar et al. & 2015 & Biodiesel production & $\mathrm{L}_{9}\left(3^{4}\right)$ \\
\hline Dhawane et al. & 2016 & Biodiesel production & $\mathrm{L}_{9}$ \\
\hline Mousavi et al. & 2017 & Inventory control system & $\mathrm{L}_{9}\left(3^{4}\right)$ \\
\hline
\end{tabular}

\section{TAGUCHI METHOD}

Taguchi Method is one of the most effective methods used in the literature to determine the effects of different levels of factors affecting a process. In other words, although Taguchi and full factorial experiment methods are identical in terms of the results they produce, the Taguchi methods reach the same results by doing far less experimentation, and thus with far less effort. For example, the number of runs in Taguchi $\mathrm{L}_{16}\left(4^{5}\right)$ orthogonal experiment design wherein each parameter has 4 levels is one fourth of the number of full factorial experimental runs. This technique is an effective alternative developed to lower the cost in optimization and parametric analysis studies, reach the results more efficiently, and identify the effects of parameters on the outcome. In the Taguchi method, factors affecting the product or process can be classified into two as controllable and uncontrollable. Orthogonal arrays particularly developed according to the number and values of parameters to determine the optimal values of control factors are used ([22]). Orthogonal arrays act an important role in decreasing the required number of experiments. In the experimental details section given below, we first present the orthogonal array used in the experiments.

A loss function is used to indicate the difference between the desired value and the result obtained from the experiment. The values coming from the experiments are transformed to signal-to-noise $(\mathrm{S} / \mathrm{N})$ ratios. In the next section, after the orthogonal design we give the details of the $\mathrm{S} / \mathrm{N}$ ratio alternatives and the one that is appropriate for our experiment, which is the higher is better.

In general, an analysis of variance (ANOVA) is provided in order to determine which factor has significant impact on the response values and which factor is insignificant. Moreover, the general success of the experiment can be extracted from the success of the factors in explaining the total variability observed in the experimental data, i.e., the $\mathrm{R}^{2}$ value. We provide the details of our ANOVA in the next section after $\mathrm{S} / \mathrm{N}$ subsection.

Finally, we first give the details of the effects of the factors and then the validation part. In the validation part, a confidence interval for the mean response value at optimal conditions are to be constructed in order to validate and verify the optimal factor levels found by the Taguchi.

\section{QUANTITATIVE RESULTS AND DISCUSSION}

In this section, the use of the Taguchi method to determine the process parameters in reading is reported step-by-step. Parameters affecting the reading speed are determined and verified.

\subsection{Orthogonal Array Experiment}

$3 * 4^{3}$ different experiment alternatives emerge in the reading experiment conducted by the present study because there are three factors, each with four levels, and each experiment is repeated three times. Put differently, if Full Factorial Experimental Design had been used, it would have been necessary to perform $3 * 4^{3}$ different experiments. However, with the Taguchi method, the effectiveness and the optimal levels of the components under focus can be figured out by performing fewer experiments, namely we just need only 16 experiments. Taguchi method offers a variety of experiment plans. The significant factors and their levels need to be identified to decide on the experiment design. The number of factors and factor levels can be increased for an experiment on reading. However, increasing the number of components was not preferred in this study as it would involve the personal characteristics of the reader. 
Similarly increasing the level of factors would decrease the significance level between the levels. $\mathrm{L}_{16}\left(4^{5}\right)$ orthogonal experiment design plan was used to determine the optimal design conditions, yet totally three factors affecting the reading speed were considered, so the fourth and fifth factor columns were left blank. Table 2 presents the $\mathrm{L}_{16}\left(4^{5}\right)$ orthogonal experiment design used and the results of the two-minute reading experiments performed in three runs under constant conditions.

Table 2. $\mathrm{L}_{16}\left(4^{5}\right)$ Experiment Plan

\begin{tabular}{|c|c|c|c|c|c|c|c|c|c|c|}
\hline \multirow{2}{*}{$\mathbf{L}_{16}\left(4^{5}\right)$} & \multirow{2}{*}{$\begin{array}{l}\text { Light } \\
\text { Level }\end{array}$} & \multirow{2}{*}{ Font Size } & \multirow{2}{*}{$\begin{array}{l}\text { Music } \\
\text { Volume }\end{array}$} & \multirow{2}{*}{ - } & \multirow{2}{*}{ - } & \multicolumn{3}{|c|}{ Number of Words Read } & \multirow{2}{*}{$\begin{array}{l}\text { Mean of } \\
\text { the trials }\end{array}$} & \multirow{2}{*}{$\begin{array}{l}\text { S/N Ratio } \\
\text { (mean) }\end{array}$} \\
\hline & & & & & & 1 & 2 & 3 & & \\
\hline 1 & 1 & 1 & 1 & 1 & 1 & 132 & 128 & 145 & 135 & 42,61 \\
\hline 2 & 1 & 2 & 2 & 2 & 2 & 141 & 162 & 150 & 151 & 43,58 \\
\hline 3 & 1 & 3 & 3 & 3 & 3 & 136 & 143 & 132 & 137 & 42,73 \\
\hline 4 & 1 & 4 & 4 & 4 & 4 & 130 & 123 & 124 & 126 & 41,98 \\
\hline 5 & 2 & 1 & 2 & 3 & 4 & 151 & 158 & 167 & 159 & 44,01 \\
\hline 6 & 2 & 2 & 1 & 4 & 3 & 172 & 184 & 178 & 178 & 45,01 \\
\hline 7 & 2 & 3 & 4 & 1 & 2 & 148 & 153 & 137 & 146 & 43,29 \\
\hline 8 & 2 & 4 & 3 & 2 & 1 & 139 & 130 & 126 & 132 & 42,39 \\
\hline 9 & 3 & 1 & 3 & 4 & 2 & 147 & 156 & 151 & 151 & 43,60 \\
\hline 10 & 3 & 2 & 4 & 3 & 1 & 142 & 136 & 131 & 136 & 42,69 \\
\hline 11 & 3 & 3 & 1 & 2 & 4 & 168 & 161 & 176 & 168 & 44,52 \\
\hline 12 & 3 & 4 & 2 & 1 & 3 & 172 & 168 & 178 & 173 & 44,74 \\
\hline 13 & 4 & 1 & 4 & 2 & 3 & 132 & 125 & 120 & 126 & 41,98 \\
\hline 14 & 4 & 2 & 3 & 1 & 4 & 135 & 129 & 122 & 129 & 42,19 \\
\hline 15 & 4 & 3 & 2 & 4 & 1 & 142 & 154 & 148 & 148 & 43,41 \\
\hline 16 & 4 & 4 & 1 & 3 & 2 & 155 & 148 & 151 & 151 & 43,60 \\
\hline
\end{tabular}

\subsection{Overall Loss Function and its $\mathrm{S} / \mathrm{N}$ ratio}

The reading experiment in this study focuses on especially the reading study done by academicians on the computer screen. The three parameters considered in the two-minute reading experiments and the four levels of each parameter are explained in further detail below.

1. Light Level: Since academicians usually read directly from the computer screen without printout, the screen brightness was set in the range of $0-33$ - 66 - 100 under constant environment light.

2. Font size: The font sizes of the texts to be read were regarded as $80 \%-120 \%-160 \%-200 \%$ of the original size of the text.

3. Music Level: The level of music in the environment during reading referred to the volume levels of $0-10-20-30$ of a music piece played on the computer.

Taguchi method identifies the optimal conditions in three categories: smaller-the-better, larger-the-better, and nominal-the-better ([23]). The mathematical denotations belonging to these approaches are as follows:

Nominal is the best: $S / N_{T}=10 \log \left(\frac{\bar{y}}{S_{y}^{2}}\right)$

Larger is better: $S / N_{L}=-10 \log \left(\frac{1}{n} \sum_{i=1}^{n} \frac{1}{y_{i}^{2}}\right)$
Smaller is better: $S / N_{S}=-10 \log \left(\frac{1}{n} \sum_{i=1}^{n} y_{i}^{2}\right)$

where $\bar{y}$ denotes the mean of all observation values, $S_{y}^{2}$ denotes the variance for $y, n$ the number of experiments, and $y_{i}$ observation values. The study preferred the $S / N_{L}$ ratio because the number of words read by academicians on the computer screen was requested to be as great as possible.

\subsection{Analysis of Variance (ANOVA)}

Ultimate aim during ANOVA analysis is to investigate and indicate the design parameters which have significant impact on the output parameters. Variances and the sum of squares are calculated and f-test values at $95 \%$ confidence level is incorporated to determine the factor which are significant on the output parameter, which is the reading speed. The ANOVA analysis for reading speed is shown in Table 3.

As can be seen from ANOVA table the chosen factors are all significant at $99 \%$ confidence level, and they are sufficient in explaining the variability of the data as the $\mathrm{R}^{2}$ value is above $90 \%$. Moreover, it can also be seen that the light level is responsible from $34,12 \%$, the font size is responsible from $3,36 \%$ and the music volume is responsible from $55,78 \%$ of the variability, respectively. 
Table 3. Results of Anova for Reading Speed

\begin{tabular}{|l|l|l|l|l|l|}
\hline Parameters & Sum of Square & Degree of Freedom & Variance & F & $\begin{array}{l}\text { Contribution } \\
\text { Percentage(\%) }\end{array}$ \\
\hline Light & 3796,50 & 3 & 1265,50 & $\mathbf{6 4 , 0 9}^{*}$ & 34,12 \\
\hline Font & 373,67 & 3 & 124,56 & $\mathbf{6 , 3 1}^{*}$ & 3,36 \\
\hline Music & 6206,50 & 3 & 2068,83 & $\mathbf{1 0 4 , 7 7}^{*}$ & 55,78 \\
\hline Error & 750,337 & 38 & 19,75 & & 6,74 \\
\hline Total & 11127 & 47 & & & \\
\hline
\end{tabular}

$\mathrm{R}-\mathrm{Sq}=93,26 \% *$ Significant at $99 \%$ confidence

\subsection{Effects of the Factors}

Performance criteria were computed by means of evaluating the results obtained from experiments, by fitting each level of every parameter into equation (2). The computed results referring to $y$-axis, and the values of parameters referring to $\mathrm{x}$-axis, Figures 1, 2, and 3 were created. Figure 1 shows the correlation between the light parameter and reading speed. Figure 2 and 3 demonstrate how font size and music volume affect reading speed, respectively. The first plot in Figure 1 corresponds to when the light level is zero. It should be noted that 0 light level does not mean that there is no light in the environment, but that the brightness of the computer screen is fixed to 0 under stable ceiling light.
While calculating the performance criteria for this plot, results of experiments $1,2,3$, and 4 , where the light level was 0 , were fitted into equation (2). Similarly, the second plot on the graph corresponds to when the light level was 33 . The performance criteria were obtained by using the results of experiments $5,6,7$, and 8 , where the light level of music volume was 33 . The other plots on the graph were calculated with the same ration based on the other values of the music volume. Similarly, the performance values in Graphs 2 and 3 were calculated according to equation (2) based on the parameters of font size and music volume. For example, the third plot on Figure 2 corresponds to level 3, where font size is 160 . To compute the performance criterion value for this plot, results of experiments $3,7,11$, and 15 , where font size is 160 , were used.

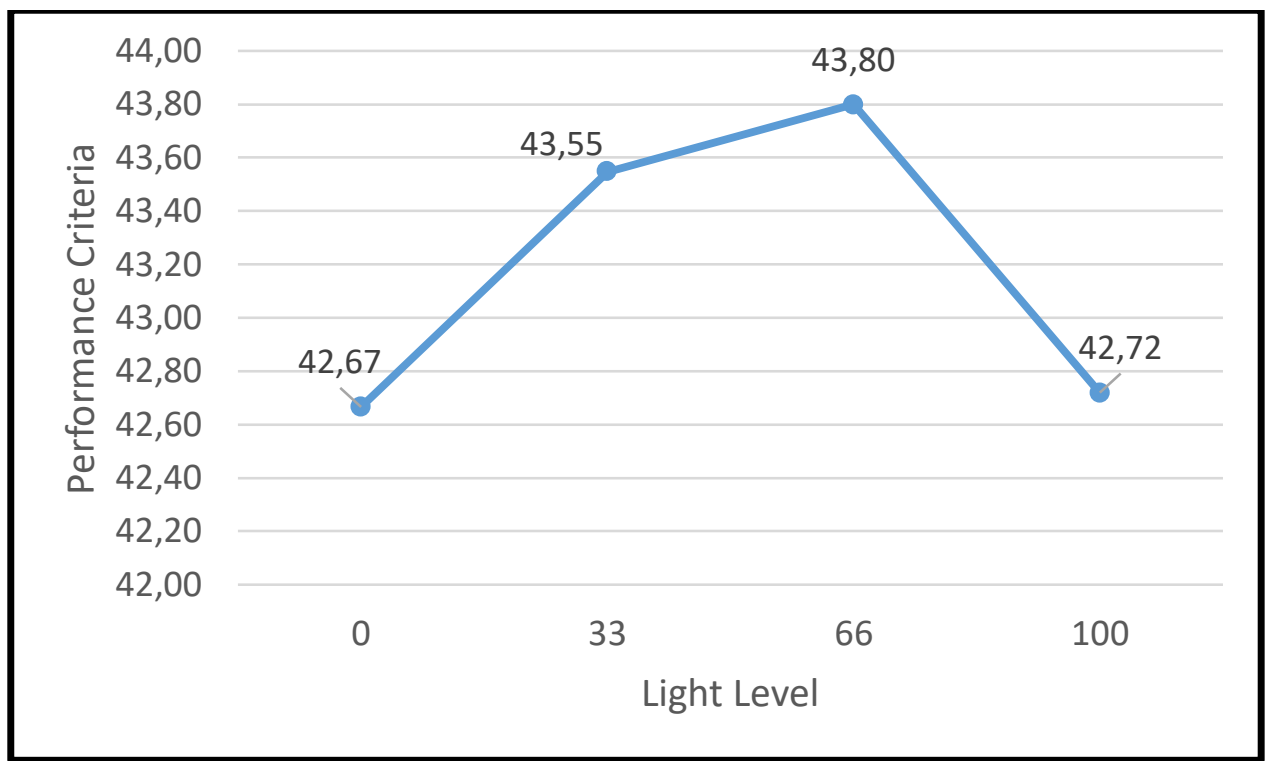

Figure 1: Effect of Light Level

Since the $S / N_{L}$ ratio is taken into account in each figure, the plot where the performance measure gains the highest value indicates the best level of the parameter concerned. This reveals that the highest reading speed is reached at level 3, where the light parameter is 66 . This result can be attributed to that too bright screen tires the eyes, thus decreases the reading speed. The fact that the performance is relatively low, especially at the plot where the light level is the highest, seems to support this possibility. It has been observed that performance values are closer when the light level is 33 and 66 , and the reading speed was observed to be low at the lowest and the highest light levels. 


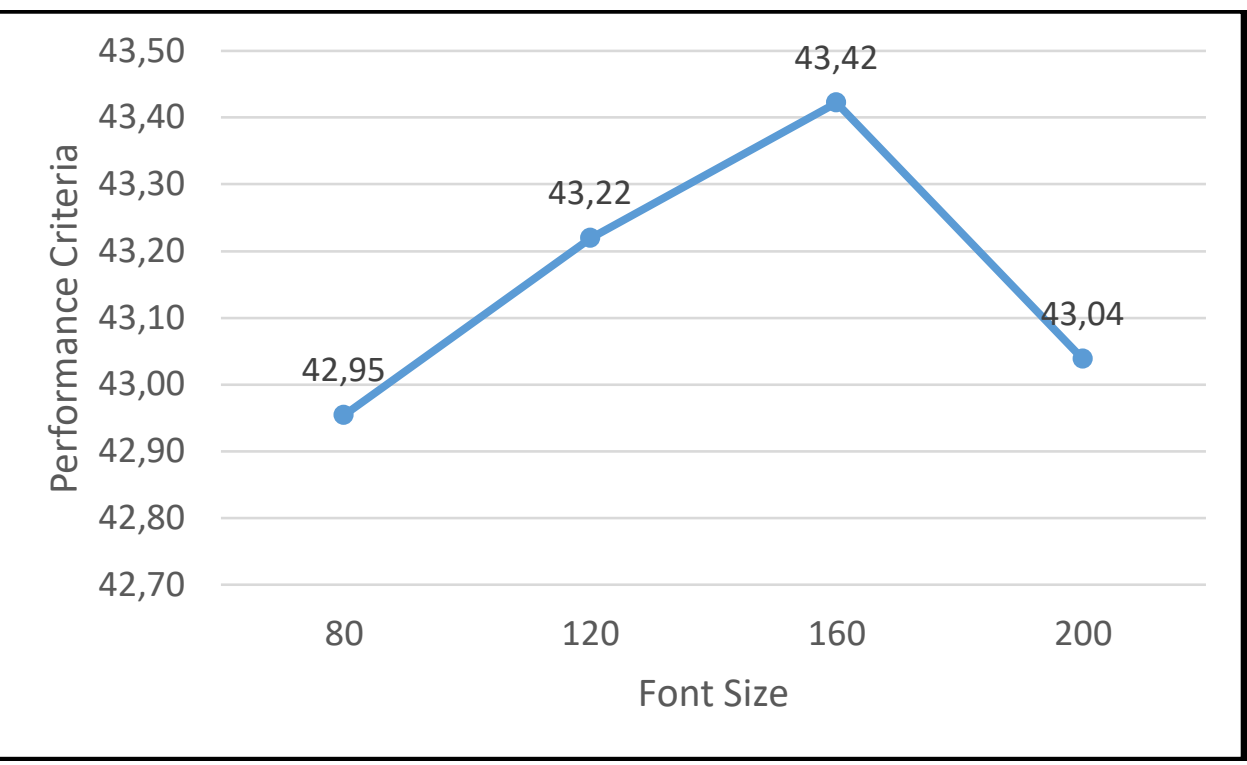

Figure 2: Effect of Font Size Level

Figure 2 illustrates the effect of font size on reading speed, showing that the bigger the font size the greater the reading speed is until 160 font size and the reading speed decreases later on. It was observed that increasing the font size had an impact until reaching the optimal level. Since the plot of the effect possess a concave structure, there was no need the increase the font size any more.

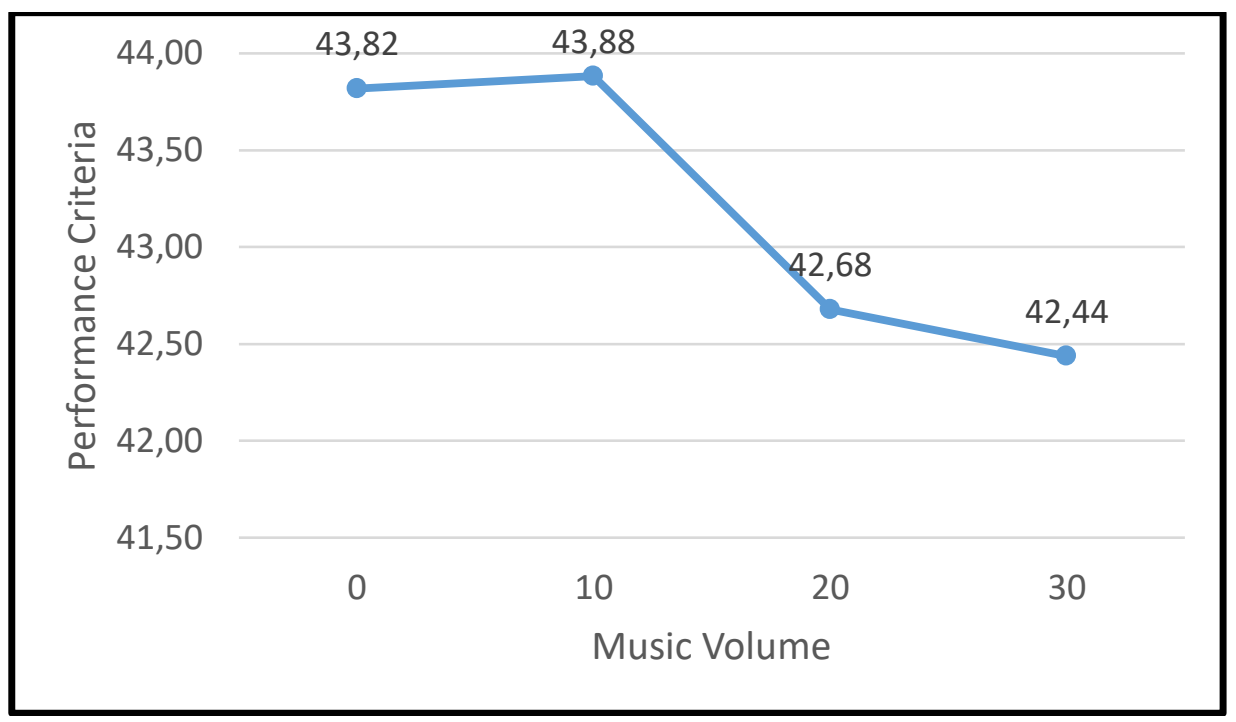

Figure 3: Effect of Music Volume

As can be seen in Figure 3, increasing the music level from 0 to 10 improved the reading speed. However, the performance criterion decreased rapidly when the music was turned up to higher volumes. This showed that reading should be done either in complete silence or with very low music in the background.

\subsection{Validation}

As can be extracted from the previous part, our Taguchi experiments yielded the following optimal factor levels affecting the reading speed: screen brightness 66 , font size
160, and music level 10. As the levels obtained were not found in the $\mathrm{L}_{16}\left(4^{5}\right)$ orthogonal experiment design plan, an additional three-run experiment was conducted for these levels, the results of which are represented in Table 4.

The estimated mean of the reading speed at the optimal conditions can be computed as ([24]): $\mu=\overline{L_{3}}+\overline{F_{3}}+\overline{M_{2}}-$ $2 \times \bar{T}$ where $\overline{L_{3}}$ represents the mean of the reading speed response value for which the light is set to third level, i.e., light level is 66 , and $\overline{F_{3}}$ represents the mean of the reading speed response value for which the font size is set to third level, i.e., the font size is 160 , and similarly $\overline{M_{2}}$ stands for the average reading speed when the music volume is at level 2, 
i.e., the music volume is 10 . Finally, $\bar{T}$ is the overall mean of the reading speed. $\overline{L_{3}}, \overline{F_{3}}, \overline{M_{2}}$ and $\bar{T}$ are respectively found out to be 157,$17 ; 149,83 ; 157,58$ and 146,58 which makes $\mu$ equals to 171,42 .

In order to find $99 \%$ confidence interval for the mean reading speed at the optimal conditions, we calculate $C I=$ $\begin{array}{llr}\sqrt{F_{0,01 ; 2 ; 15} V_{e}\left(\frac{1}{n_{e f f}}\right)} \text { where } & F_{0,01 ; 2 ; 15}=6,36, & V_{e}=19,75 \\ \text { from } \quad 3 \quad \text { and } & n_{\text {eff }}= \\ \frac{\text { number of experiments }}{1+\text { total dof used for calculation of } \mu}=\frac{16}{1+3+3+3}=1,6 & \text { which }\end{array}$ makes $C I=8,86$. The $99 \%$ confidence interval for the mean is then $\mu \pm C I$ which is $171,42 \pm 8,86$. In other words, the $99 \%$ confidence interval is $(162,56-180,28)$. We have tried to conduct the experiment under the optimal conditions in order to see whether it complies with the above mentioned confidence interval. The results are provided in Table 4. It can be seen that the average result lays within the found confidence interval and validates our findings.

Table 4. The experiment results concerning optimal levels of reading factors

\begin{tabular}{|l|l|l|l|l|l|l|l|l|l|l|}
\hline \multirow{2}{*}{$\mathbf{L}_{16}\left(\mathbf{4}^{\mathbf{5}}\right)$} & $\begin{array}{l}\text { Light } \\
\text { Level }\end{array}$ & Font Size & $\begin{array}{l}\text { Music } \\
\text { Volume }\end{array}$ & - & - & \multicolumn{2}{|l|}{ Number of Words Read } & $\begin{array}{l}\text { Mean of } \\
\text { the trials }\end{array}$ & $\begin{array}{l}\text { S/N Ratio } \\
(\mathbf{m e a n})\end{array}$ \\
\hline $\mathbf{1}$ & 3 & 3 & 2 & - & - & 182 & 175 & 181 & 179,33 & 45,07 \\
\hline
\end{tabular}

\section{DISCUSSION AND CONCLUSION}

In this study, the Taguchi method was used to determine the optimal levels of factors affecting the reading speed of the academicians who read under constant environment light in the room. L16(45) orthogonal test design plan was adopted for experiments, and the significant factors were considered as level of light, font size, and music level. Each factor was assigned four levels, and the performance criterion was accepted to be the number of words read in two minutes. The experiment results were evaluated based on the-larger- isbest criterion. Figures were created demonstrating the effect of each significant factor on the process. The results revealed the following ideal conditions for the reading study

\section{REFERENCES}

[1].Taguchi, G., 1986. Introduction to quality engineering: designing quality into products and processes.

[2].Zhang, J.Z., Chen, J.C. and Kirby, E.D., 2007. Surface roughness optimization in an end-milling operation using the Taguchi design method. Journal of materials processing technology, 184(1), pp.233-239.

[3].Nalbant, M., Gökkaya, H. and Sur, G., 2007. Application of Taguchi method in the optimization of cutting parameters for surface roughness in turning. Materials \& design, 28(4), pp.1379-1385.

[4].Tzeng, C.J., Lin, Y.H., Yang, Y.K. and Jeng, M.C., 2009. Optimization of turning operations with multiple performance characteristics using the Taguchi method and Grey relational analysis. Journal of materials processing technology, 209(6), pp.2753-2759.

[5].Kilickap, E., 2010. Optimization of cutting parameters on delamination based on Taguchi method during drilling of GFRP composite. Expert Systems with Applications, 37(8), pp.6116-6122.

[6].Asiltürk, I. and Neşeli, S., 2012. Multi response optimisation of CNC turning parameters via Taguchi conducted: screen brightness level 66 , font size 160 , and music volume 10

It is hoped that the present study will both help increase the reading efficiency and shed light onto the less harmful environment conditions for eye health, by means of identifying the optimal values of factors affecting the reading speed. Nevertheless, it is suggested that further studies with a larger scope, e.g. those focusing on other factors such as using eye-glasses, or gender, be carried out at different times and under different conditions. The limitation of the study is that only three controllable factors were taken into account, none of which was concerning personal characteristics. Still, it is hoped that this study will provide the basis for further larger-scale studies.

method-based response surface analysis. Measurement, 45(4), pp.785-794.

[7].Engin, A.B., Özdemir, Ö., Turan, M. and Turan, A.Z., 2008. Color removal from textile dyebath effluents in a zeolite fixed bed reactor: Determination of optimum process conditions using Taguchi method. Journal of hazardous materials, 159(2), pp.348-353.

[8].Lin, Y.C., Wang, A.C., Wang, D.A. and Chen, C.C., 2009. Machining performance and optimizing machining parameters of $\mathrm{Al} 2 \mathrm{O} 3-\mathrm{TiC}$ ceramics using EDM based on the Taguchi method. Materials and manufacturing processes, 24(6), pp.667-674.

[9].Eşme, U., 2009. Application of Taguchi method for the optimization of resistance spot welding process. Arabian Journal for Science and Engineering, 34(2), p.519.

[10]. Kamaruddin, S., Khan, Z.A. and Foong, S.H., 2010. Application of Taguchi method in the optimization of injection moulding parameters for manufacturing products from plastic blend. International Journal of Engineering and technology, 2(6), p.574.

[11]. Kuo, C.F.J., Su, T.L., Jhang, P.R., Huang, C.Y. and Chiu, C.H., 2011. Using the Taguchi method and grey relational analysis to optimize the flat-plate collector process 
with multiple quality characteristics in solar energy collector manufacturing. Energy, 36(5), pp.3554-3562.

[12]. Sapakal, S.V. and Telsang, M.T., 2012. Parametric optimization of MIG welding using Taguchi design method. Int J Adv Eng Res Stud, 1(4), pp.28-30.

[13]. Kotcioglu, I., Cansiz, A. and Khalaji, M.N., 2013. Experimental investigation for optimization of design parameters in a rectangular duct with plate-fins heat exchanger by Taguchi method. Applied Thermal Engineering, 50(1), pp.604-613.

[14]. Sivasakthivel, T., Murugesan, K. and Thomas, H.R., 2014. Optimization of operating parameters of ground source heat pump system for space heating and cooling by Taguchi method and utility concept. Applied Energy, 116, pp.76-85.

[15]. Kumar, R.S., Sureshkumar, K. and Velraj, R., 2015. Optimization of biodiesel production from Manilkara zapota (L.) seed oil using Taguchi method. Fuel, 140, pp.90-96.

[16]. Dhawane, S.H., Kumar, T. and Halder, G., 2016. Biodiesel synthesis from Hevea brasiliensis oil employing carbon supported heterogeneous catalyst: optimization by Taguchi method. Renewable Energy, 89, pp.506-514.

[17]. Mousavi, S.M., Bahreininejad, A., Musa, S.N. and Yusof, F., 2017. A modified particle swarm optimization for solving the integrated location and inventory control problems in a two-echelon supply chain network. Journal of
Intelligent Manufacturing, 28(1), pp.191-206.

[18]. Paterson, D.G. and Tinker, M.A., 1932. Studies of typographical factors influencing speed of reading. X. Style of type face. Journal of Applied Psychology, 16(6), p.605.

[19]. Berman, I.R. and Bird, C., 1933. Sex differences in speed of reading. Journal of Applied Psychology, 17(3), p.221.

[20]. Chung, S.T., 2007. Learning to identify crowded letters: does it improve reading speed?. Vision research, 47(25), pp.3150-3159.

[21]. Baynal, K., Gürsoy, A., Gülkaç, H. and Aktel, A., 2011. Okuma Hızını Etkileyen Önemli Unsurların Deney Tasarımı İle Optimizasyonu. Üretim Araştırmaları Sempozyumu, bildiriler kitab1, 428-436.

[22]. Alsaran, A., Çelik, A. and Çelik, C., 2002. Determination of the optimum conditions for ion nitriding of AISI 5140 steel. Surface and Coatings Technology, 160(2), pp.219-226.

[23]. Krishnaiah, K. and Shahabudeen, P., 2012. Applied design of experiments and Taguchi methods. PHI Learning Pvt. Ltd.

[24]. Asiltürk, I., \& Neşeli, S. (2012). Multi response optimisation of CNC turning parameters via Taguchi method-based response surface analysis. Measurement, 45(4), 785-794. 